\title{
Historic decline in primary productivity in western Gulf of Alaska and eastern Bering Sea: isotopic analysis of northern fur seal teeth
}

\author{
S. D. Newsome ${ }^{1, *}$, M. A. Etnier ${ }^{2}$, C. M. Kurle ${ }^{3}$, J. R. Waldbauer ${ }^{4}$, C. P. Chamberlain ${ }^{5}$, \\ P. L. Koch ${ }^{6}$ \\ ${ }^{1}$ Carnegie Institution of Washington, Geophysical Laboratory, 5251 Broad Branch Road NW, Washington, DC 20015, USA \\ ${ }^{2}$ Anthropology Department, University of Washington, Box 353100, Seattle, Washington 98195-3100, USA \\ ${ }^{3}$ Center for Ocean Health, University of California-Santa Cruz, 100 Shaffer Road, Santa Cruz, California 95060, USA \\ ${ }^{4}$ Massachusetts Institute of Technology, 77 Massachusetts Avenue, E34, Cambridge, Massachusetts 02139, USA \\ ${ }^{5}$ Department of Geological and Environmental Sciences, Stanford University, Stanford, California 94305-2115, USA \\ ${ }^{6}$ Earth Sciences Department, University of California-Santa Cruz, 1156 High Street, Santa Cruz, California 95064, USA
}

\begin{abstract}
The cause(s) for the declines in marine mammal populations in the North Pacific and Bering Sea over the past 30 yr are unknown, despite progress in understanding the present ecology of this system. Explanations that attribute the declines to long-term decreases in marine productivity and/or short-term shifts in oceanographic conditions have been offered, but few studies have explored the issue from an explicitly historical perspective. Here we present a high-resolution, $52 \mathrm{yr}$ time series of $\delta^{13} \mathrm{C}$ and $\delta^{15} \mathrm{~N}$ values for teeth of juvenile male northern fur seal Callorhinus ursinus collected from a single colony on Saint Paul Island, Alaska in the eastern Bering Sea. Mean annual $\delta^{13} \mathrm{C}$ declined by $\sim 1.1 \%$ from 1948 to 2000 , while long-term mean annual $\delta^{15} \mathrm{~N}$ did not significantly change. The relatively small but significant long-term decrease in $\delta^{13} \mathrm{C}$ most likely reflects anthropogenically-driven changes in surface ocean carbon reservoirs and not a decline in primary productivity in the North Pacific and Bering Sea system. To assess short-term shifts in the time series, we detrended the $\delta^{13} \mathrm{C}$ data; the $\delta^{15} \mathrm{~N}$ time series did not require a correction. The corrected $\delta^{13} \mathrm{C}$ and uncorrected $\delta^{15} \mathrm{~N}$ values showed low amplitude oscillations with a frequency of $\sim 20$ to 25 yr that are roughly in phase through time. The relative timing of these oscillations suggest they may be driven by shifts in the Pacific Decadal Oscillation (PDO); however, the frequency of cycles in our time series is approximately half as long as the frequency of the PDO. Finally, mean $\delta^{13} \mathrm{C}$ and $\delta^{15} \mathrm{~N}$ values suggest that juvenile males modify their migration patterns by Age 3 (GL3, the third year of growth). Specifically, they remain in high-latitude waters year-round (southern Bering Sea and/or western Gulf of Alaska).
\end{abstract}

KEY WORDS: Northern fur seals $\cdot$ Callorhinus ursinus $\cdot$ Stable isotopes $\cdot$ Teeth annuli $\cdot$ Primary productivity $\cdot$ Suess effect $\cdot$ North Pacific Ocean $\cdot$ Bering Sea

\section{INTRODUCTION}

Northern fur seals range and breed from southern California to the Aleutian Islands, and farther west to northern Japan, but $\sim 60 \%$ of their global population breed on the Pribilof Islands in the Bering Sea. The large Pribilof stock spends late June to early Novem- ber on the colony, after which adult females range as far south as California, while adult males continue to forage in the Gulf of Alaska and Bering Sea during the winter months (Gentry 1998). The seasonal migratory patterns of juveniles are poorly resolved. It is believed that juvenile males migrate from temperate latitude North Pacific waters into the Gulf of Alaska during the 
early spring months, then into western Alaska and the Aleutian Islands in late spring/early summer, and finally into the eastern Bering Sea by the beginning of the breeding season in June to July (Bigg 1990).

Over the past 150 yr northern fur seal stocks on the Pribilof Islands have undergone shifts in population size. Populations were decimated by pre-20th century commercial harvests that nearly led to the species' extinction by the 1890s (Scheffer et al. 1984). An estimated $\sim 2.5$ million seals were slaughtered as part of the fur trade from 1780 to 1870 , and by the early 1900 s Pribilof population estimates had reached a low of 215 000 individuals. As a result, the North Pacific Fur Seal Convention was signed in 1911 by the United States, Canada, Russia, and Japan, which limited hunting to terrestrial-based culling of immature males. Following protection, the Pribilof stock grew to $>1$ million by 1956, at which point a female harvest was instituted (York \& Hartley 1981). The population dropped to $<300000$ by 1968 and the female harvest was stopped. Since then, surprisingly, the population has continued to decline (York 1990). As a result, Callorhinus ursinus was designated as 'depleted' under the United States Marine Mammal Protection Act in 1988 because population estimates had declined to less than $50 \%$ of levels observed in the late 1950s. The most recent population estimates are lower than those that led to international protection in 1911 (Towell et al. 2006). As a result, the Bering Sea stock of $C$. ursinus is now being considered for 'threatened' status under the United States Endangered Species Act.

A host of explanations have been proposed for recent declines in northern fur seals and other North Pacific marine mammal populations, including resource competition with fisheries, oceanic or climate change, subsistence hunting, poaching, incidental losses in fishing gear, natural predation, disease, and pollutants (National Research Council 2002). Some investigators have suggested that the decline is related to shifts in the quantity and/or quality of prey species (Trites 1992, Sinclair et al. 1994). One of the questions yet to be resolved is whether or not such prey fluctuations are due to the 'top-down' impacts of commercial fishing or to natural variations in prey quality due to 'bottom-up' climatic forcing. Complicating the issue is the fact that northern fur seals prey on over 60 different kinds of fish and squid (Kajimura 1984, Sinclair et al. 1994, Antonelis et al. 1997). This makes it difficult to assess whether the ultimate cause of recent declines is to be found in decreased numbers of just a few primary prey species due to fishing pressure or to a decrease in the overall quality of the seals' forage through a complex combination of fishing, long-term oceanographic cycles, and short-term climatic events. Dietary records derived from gut content and/or scat analysis that span several years (or decades) are rare, may contain inherent biases (Bigg \& Fawcett 1985), but can be used to characterize large shifts in prey type and constrain dietary data derived from other sources, such as fatty acid or stable isotope analysis.

An idea that has received a considerable amount of attention recently is that the North Pacific and Bering Sea ecosystems experienced a decline in primary production over the last few decades due to oceanographic and/or climatic shifts, as inferred from time series of stable isotope values in marine consumers (Schell 2000, 2001, Cullen et al. 2001, Hirons et al. 2001, Hunt et al. 2002, Hobson et al. 2004). Stable isotope analysis provides a means of studying past diets through the examination of historic tissue samples such as bones, teeth, and preserved skins in museum collections. Isotopic differences at the base of the food web are passed to higher trophic levels with small, characteristic offsets and have served as natural labels in studies of marine mammal foraging ecology (Schell et al. 1989, Ostrom et al. 1993, Hobson et al. 1997, Burton \& Koch 1999, Walker \& Macko 1999, Kurle \& Worthy 2001). Important to many of these studies is the characteristic increase of $\sim 1$ and $~ 3-5 \%$ in $\delta^{13} \mathrm{C}$ and $\delta^{15} \mathrm{~N}$ values respectively with each trophic step, which permits study of food web dynamics and trophic status (DeNiro \& Epstein 1978, 1981, Minagawa \& Wada 1984). Laboratory and field studies have recognized a positive relationship between phytoplankton growth rate (i.e. primary production) phytoplankton carbon isotope values (discussed in detail in 'Results: Long-term trends') that is commonly cited in the interpretation of long-term trends in consumer $\delta^{13} \mathrm{C}$ values (Schell 2000, Hirons et al. 2001, Hobson et al. 2004).

Three isotopic time series are now available from the Bering Sea-North Pacific. The first, by Schell (2000), who examined the $\delta^{13} \mathrm{C}$ and $\delta^{15} \mathrm{~N}$ values of the baleen of bowhead whales harvested in the western Bering and Beaufort Seas, presents the strongest case for a historical decrease in primary production in the region. Schell $(2000,2001)$ found a significant long-term decline in carbon and nitrogen isotope values between 1965 and 1997, and estimated that the $\delta^{13} \mathrm{C}$ decline $(\sim 2.7 \%$ o) signified a $\sim 30$ to $40 \%$ decline in primary productivity in the Bering Sea. Average annual $\delta^{15} \mathrm{~N}$ for the bowheads analyzed decreased by $\sim 1.3 \%$ from 1952 to 1997. Since bowhead whales migrate seasonally between regions with very different isotopic values at the base of the food web, it is difficult to discount the possibility that the isotopic shifts documented in bowheads were influenced by temporal shifts in foraging zone among this relatively small set of individual whales (1947 to 1965 record derives from analysis of 1 to 4 ind.). 
A study by Hirons et al. (2001) sought to assess the patterns documented by Schell (2000) through examination of bone collagen isotope values from 3 pinniped species, comprising Steller sea lions Eumetopias jubatus, harbor seals Phoca vitulina and Callorhinus ursinus. Were similar trends to be found in a diverse suite of species with different migratory and foraging behaviors, then an explanation involving a shift in isotope values at the base of the entire Bering Sea-North Pacific ecosystem would be favored. Hirons et al. (2001) found an average $\delta^{13} \mathrm{C}$ decline of $\sim 2.0 \%$ from 1951 to 1996 in the 3 species. Unfortunately, age and sex data were not available for most specimens, making interpretations problematic, as pinnipeds are extremely sexually dimorphic (Perrin et al. 2002) and both size and age are strongly related to trophic position in marine systems (Michener \& Schell 1994). Furthermore, because of bone turnover, which varies during ontogeny, bone collagen isotope values integrate dietary information over a relatively long and variable time span in the life of an individual. Lastly, specimens from the Bering Sea and Gulf of Alaska were combined in the analysis, making it difficult to interpret the observed isotopic trends. For example, blood from Steller sea lions sampled in February and March 1999 over a large geographic area (comprising the eastern Bering Sea, the Gulf of Alaska, and Puget Sound) showed significant variation in stable carbon and nitrogen isotope values with location of sample collection (Kurle \& Sinclair 2003). The research by Hirons et al. (2001) underscores the importance of constraining potential sources of isotopic variation such as collection locality, gender, and age group.

Finally, Hobson et al. (2004) examined inorganic $\delta^{13} \mathrm{C}$ and organic $\delta^{15} \mathrm{~N}$ values of Steller sea lion dentin from canine teeth collected in the Gulf of Alaska from the 1960s to the 1980s. These data were combined with feather isotope data from tufted puffins Fratercula cirrhata and crested auklets Aethia crisatella to explore temporal changes in food webs in response to the 1976 climate regime shift (Ebbesmeyer et al. 1991). From 1960 to $1982, \delta^{13} \mathrm{C}$ of the inorganic fraction of Steller sea lion tooth dentin decreased slightly $(\sim 0.5 \%)$ and $\delta^{15} \mathrm{~N}$ of the organic portion increased ( 0.5\%). Hobson et al. (2004) interpreted these subtle trends as reflecting an increase in trophic level and thus a shift to more pelagic prey. This interpretation is consistent with that of other dietary studies (Sinclair \& Zeppelin 2002, Kurle \& Sinclair 2003) that indicated greater incorporation of large demersal species (e.g. walleye pollock Theragra chalcogramma and Pacific cod Gadus macrocephalus) over small species (e.g. capelin Mallotus villosus and Pacific herring Clupea pallasii) in Steller sea lion diets since the late 1970s. As in the study by Hirons et al. (2001), historic sea lion specimens were collected from colonies over a relatively broad geographic region, from Cape Suckling $\left(144^{\circ} \mathrm{W}\right)$ to the Shumagin Islands $\left(160^{\circ} \mathrm{W}\right)$. Furthermore, a more thorough isotopic study of common Steller sea lion prey items in the region would help substantiate claims that the relatively small isotopic shifts observed are due to dietary changes and not to changes in food web isotope values.

In the present study, we attempt to control factors that have confounded interpretation of prior isotopic time series. We present isotopic data from a historic time series of juvenile male northern fur seal canine teeth harvested annually from a single colony on Saint Paul Island (Pribilof Islands, Alaska) in the Bering Sea, analyzing only samples from the third year of growth (GL3). There were 3 primary questions we wished to address: (1) Are long-term trends evident in the time series? If so, are these trends attributable to a change in foraging behavior or to shifts in baseline food web isotope values resulting from either changes in primary production or input of anthropogenically derived, ${ }^{13} \mathrm{C}$ depleted $\mathrm{CO}_{2}$ into the surface ocean? (2) Are there short-term shifts evident in the time series and how do they relate to known climatic/oceanographic cycles in the North Pacific, such as the Pacific Decadal Oscillation (PDO) and/or El Niño Southern Oscillation (ENSO)? (3) Can the tooth dentin isotopic composition of $3 \mathrm{yr}$ old juvenile male northern fur seals be used to constrain average annual foraging latitude when compared to previously published isotope values from adult males and females?

To constrain interpretations of the isotopic trends we observed, we used previously published data on historic dietary shifts compiled from gut content and scat analysis as well as isotope values of common Callorhinus ursinus prey items.

\section{MATERIALS AND METHODS}

Canine tooth collections. We analyzed 220 juvenile male northern fur seal teeth collected throughout the 20th century. Over the past century, Callorhinus ursinus were harvested annually from the Pribilof Islands in the eastern Bering Sea. The harvest was conducted commercially from 1918 to 1984 but was terminated due to severe declines in population size (National Marine Fisheries Service 1993). After cessation of the commercial harvest, a small subsistence harvest was initiated, which continues to the present day (York 1990, Sinclair \& Robson 1999). Upper canine teeth of 2 to $5 \mathrm{yr}$ old juvenile males were collected annually from $\sim 20 \%$ of the individuals taken in the summer harvest since 1948 to monitor changes in the age structure of harvested males (Roppel \& Davey 1965, 
Scheffer 1984, York 1990). In an attempt to control for potential variability in foraging behavior and location among rookeries on the Pribilof Islands, we only sampled individuals harvested from the Reef Rookery complex on the southern shore of Saint Paul Island, Alaska.

All canine teeth for the 1948 to 2000 time series are from 3 yr old juvenile males. Canines are not available from Reef Rookery for 1951, 1963, 1967, 1968, 1969, 1987, 1988, 1989, 1990, 1996, and 1998. Callorhinus ursinus canines harvested during commercial and subsistence harvests from 1948 to 2000 are archived in the scientific research collection at the National Marine Mammal Laboratory in Seattle, Washington. A limited number of juvenile male canine tooth samples are available from the commercial harvests of the early 20th century (1910 to 1918). These teeth are from seals culled on Saint Paul Island but the precise harvest locations were not recorded. We collected tooth annuli samples that represent dietary information for males in 1914 and 1915. Early 20th century specimens are archived at the Smithsonian Institution in Washington, DC.

Tooth sectioning and sampling. Pinniped tooth dentin contains annuli that have been used to study age, growth rate, age at sexual maturity, season of birth/ death, foraging behavior and age at weaning (Scheffer 1950, Bengston 1988, Baker 1991, Hobson \& Sease 1998, Newsome et al. 2006). The isotopic composition of each annulus is assumed to represent a time-averaged value for an entire year's growth, and thus the average isotopic value of an individual's diet for that particular year. Many pinniped species exhibit ontogenetic shifts in foraging behavior that can be traced with isotopic analysis. For example, the first year of growth is marked by a heavy dependence on milk, as nursing is the primary source of nutrients for young pups. This dependence yields higher $\delta^{15} \mathrm{~N}$ values and, depending on the species, lower $\delta^{13} \mathrm{C}$ values in the tissues of nursing individuals, including tooth dentin (Hobson \& Sease 1998, Burton et al. 2001, Newsome et al. 2006). Active foraging and incorporation of solid food in subsequent years leads to a drop in $\delta^{15} \mathrm{~N}$ values and, depending on the species, an increase in $\delta^{13} \mathrm{C}$ values (Newsome et al. 2006). As pinnipeds mature and increase in size, both their $\delta^{13} \mathrm{C}$ and $\delta^{15} \mathrm{~N}$ values may rise as they take larger prey at higher trophic levels (Minagawa \& Wada 1984, Hobson et al. 1997), or may shift as they begin to forage in different locations (Hobson et al. 1997, Burton \& Koch 1999).

To avoid the confounding influences of nursing and to minimize the potential for differences in foraging location, we sampled only dentin from the third growth layer (GL3) from each northern fur seal tooth. Isotope values from GL3 represent growth from the year of collection combined with the latter half of the previous year's growth. For example, the third annulus of a canine tooth from an individual harvested in the summer of 2000 represents growth for the previous 12 mo and includes dentin deposited since the summer of 1999. In the case of samples from the 1948 to 2000 time series, GL3 was present adjacent to the pulp cavity of the tooth. For samples from the early 20th century $(1914,1915)$ we milled GL3 from a longer series of growth increments.

We randomly selected 5 canine tooth samples from juvenile males from each year. Teeth were mounted on a wooden block and sectioned slightly to one side of the longitudinal mid-line with a diamond saw. Age estimates were verified via visual examination of annuli from each sectioned half. The larger section was then polished with 600-grit sandpaper and mounted on a wooden jig attached to the drill sample stage using 2-sided tape. Dentin annuli were drilled using a highresolution Merchantek micromill drilling system (Department of Geological \& Environmental Sciences, Stanford University). We varied the width of the drill bit from 600 to $1000 \mu \mathrm{m}$ to accommodate variations in thickness of GL3 among individuals. Depending on the thickness of the annuli, $\sim 10$ to $20 \mathrm{mg}$ of tooth dentin was recovered from each specimen.

Samples of northern fur seal prey. Relevant prey samples were collected opportunistically in the Bering Sea during trawls by the National Marine Fisheries Service and frozen whole upon collection until they were processed for analysis. Whole prey items were homogenized with tissue grinders and lypholized for $\sim 24 \mathrm{~h}$. Lipids were removed using petroleum ether (Dobush et al. 1985) in a Soxhlet extractor for $\sim 24 \mathrm{~h}$. Prey samples were then oven-dried at $\sim 60^{\circ} \mathrm{C}$ to remove any remaining solvent and sealed $(\sim 1.5 \mathrm{mg})$ in tin capsules.

$\delta^{13} \mathbf{C}$ and $\delta^{15} \mathrm{~N}$ analyses. To isolate collagen from tooth dentin, powdered dentin samples were demineralized in $0.25 \mathrm{~N} \mathrm{HCl}$ for 24 to $36 \mathrm{~h}$ at $5^{\circ} \mathrm{C}$, and the resulting protein was vacuum concentrated and lypholized. Dried collagen samples $(\sim 1.5 \mathrm{mg})$ were sealed in tin capsules and analyzed using a Costech elemental analyzer interfaced with a Finnegan Delta Plus isotope ratio mass spectrometer (Department of Geological and Environmental Sciences, Stanford University). As a control for the quality of dentin collagen, we measured the carbon-to-nitrogen $(\mathrm{C}: \mathrm{N})$ ratios of each sample to test the possibility that isotopic values were altered postmortem. In addition, the powdered tooth dentin samples were not lipid-extracted, and we wanted to ensure that our samples did not contain ${ }^{13} \mathrm{C}$ depleted lipids, which would have led to an increase in the C:N ratio relative to pure protein (DeNiro \& Epstein 1978). The atomic C:N ratios of all tooth dentin samples were 3.2 to 3.4 , well within the range that characterizes unaltered, pure protein (Ambrose 1990). 
Results are expressed in delta notation using the equation, $\delta^{13} \mathrm{C}$ or $\delta^{15} \mathrm{~N}=1000\left[\left(\mathrm{R}_{\text {sample }} / \mathrm{R}_{\text {standard }}\right)-1\right]$, where $R_{\text {sample }}$ and $\mathrm{R}_{\text {standard }}$ are the ${ }^{13} \mathrm{C}:{ }^{12} \mathrm{C}$ or ${ }^{15} \mathrm{~N}:{ }^{14} \mathrm{~N}$ ratios of the sample and standard respectively. The standards are Vienna-Pee Dee Belemnite limestone (V-PDB) for carbon and atmospheric $\mathrm{N}_{2}$ for nitrogen. The units are expressed as parts per thousand (ppt, \%o). Repeated measurements of a gelatin standard $(n=100)$ yielded a standard deviation of $<0.2 \%$ for both $\delta^{13} \mathrm{C}$ and $\delta^{15} \mathrm{~N}$. Duplicate isotopic measurements were performed on $\sim 20 \%$ of all unknown samples and yielded a mean absolute difference of less than $0.2 \%$ for $\delta^{13} \mathrm{C}$ and $\delta^{15} \mathrm{~N}$.

Statistical analysis. Statistical tests were calculated using the software programs JMP (Version 5.0) and Matlab (Version 7.1). To characterize long-tem trends in each isotope time series (see Fig. 1), we applied a simple linear model to the raw mean annual $\delta^{13} \mathrm{C}$ and $\delta^{15} \mathrm{~N}$ values using JMP. To characterize shortterm shifts in the de-trended mean annual $\delta^{13} \mathrm{C}$ and raw $\delta^{15} \mathrm{~N}$ time series we used the curve fitting toolbox in Matlab. Three distinct models were applied to each isotope time series, including a linear, 5th order polynomial, and 2nd order Fourier series function. Intra-annual variability in isotope values was incorporated into each model by weighing each mean annual value by its standard error. Using this technique we could also compute $95 \%$ confidence intervals for each model.

Given the complex interactions among the large number of biological and physical variables known to influence the isotopic composition of pelagic food webs, we did not take an information-theoretic approach to characterize our time series, such as Akaike's information criterion, in which models are constructed a priori using a set of variables believed to explain (usually through direct observation) a set of ecological processes or patterns. Modeling the impacts of physical parameters (i.e. temperature), known to fluctuate with short- and long-term climatic shifts (i.e. ENSO and/or PDO) in the North Pacific Ocean, on the isotopic composition of primary producers is beyond the scope of our study. However, our data set may warrant an information-theoretic approach as more information regarding the processes controlling pelagic food web isotope values arises through laboratory and field-based experiments and, more importantly, more knowledge is obtained on how these variables fluctuate in response to observed short- and long-term climatic shifts in the North Pacific Ocean.

Differences in the $\delta^{13} \mathrm{C}$ and $\delta^{15} \mathrm{~N}$ values of dentin and bone collagen among ontogenetic groups were assessed in JMP using a 1-way analysis of variance (ANOVA) followed by a post-hoc Tukey's pairwise comparison test.

\section{RESULTS AND DISCUSSION}

\section{Long-term trends}

Data

Mean annual GL3 $\delta^{13} \mathrm{C}$ decreased by $\sim 1.1 \%$ but $\delta^{15} \mathrm{~N}$ did not change significantly from 1948 to 2000 . Fig. 1 and Table 1 present mean annual GL3 $\delta^{13} \mathrm{C}$ and $\delta^{15} \mathrm{~N}$ values from 1948 to 2000; Table 2 presents mean ( $\pm 1 \mathrm{SD}$ ) decadal GL3 $\delta^{13} \mathrm{C}$ and $\delta^{15} \mathrm{~N}$ values. The negative trend in mean annual $\delta^{13} \mathrm{C}$ since 1948 is significant $($ ANOVA, $F$-ratio $=48.88, p<0.0001)$ and can be fit with a linear regression model with a slope of $-0.0215 \%$ o $\mathrm{yr}^{-1}$ and an $\mathrm{R}^{2}$ value of 0.55 (Fig. 1A). Standard deviations around each mean annual $\delta^{13} \mathrm{C}$ value range from \pm 0.1 to $0.6 \%$. There is no significant longterm trend evident in the $\delta^{15} \mathrm{~N}$ data when fit with a linear regression model (Fig. 1B, (see Table 3; slope = -0.0033 , adjusted $\left.\mathrm{R}^{2}=0.02, \mathrm{p}>0.05\right)$. Standard deviations around each annual mean $\delta^{15} \mathrm{~N}$ value range from \pm 0.5 to $1.5 \%$.
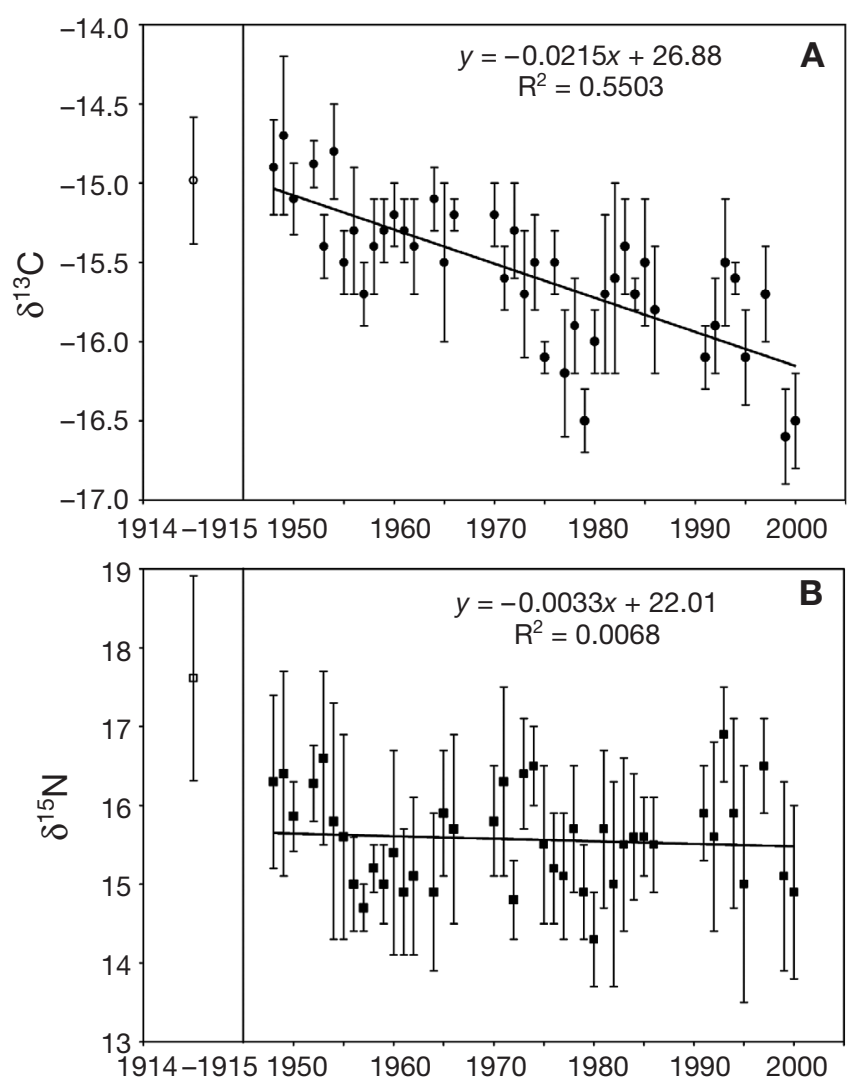

Fig. 1. Callorhinus ursinus. Time series of mean $( \pm 1 \mathrm{SD})$ values of (A) $\delta^{13} \mathrm{C}$ and (B) $\delta^{15} \mathrm{~N}$ in tooth dentin of $3 \mathrm{yr}$ old juvenile males (GL3); 5 randomly chosen individuals were analyzed per year. Regression lines and equations are linear models for each time series; vertical line separates 1914 and 1915 data from more recent (1948 to 2000) data 
Table 1. Callorhinus ursinus. Mean $( \pm 1 \mathrm{SD}) \delta^{13} \mathrm{C}$ and $\delta^{15} \mathrm{~N}$ values of dentin collagen (third growth layer, GL3) harvested from juvenile male from Pribilof Islands; 5 randomly chosen juvenile male individuals were sampled per year. Specimens from 1948 to 2000 are from Reef Rookery complex on Saint Paul Island, Alaska. Precise colony of origin for specimens from 1914 and 1915 is not known; however, these individuals were harvested on Saint Paul Island. Atomic C:N ratios of all tooth dentin samples were 3.2 to 3.4 (see 'Materials and methods')

\begin{tabular}{|c|c|c|}
\hline Harvest year & $\delta^{13} \mathrm{C}$ & $\delta^{15} \mathrm{~N}$ \\
\hline 1914-1915 & $-15.0 \pm 0.4$ & $17.6 \pm 1.3$ \\
\hline 1948 & $-14.9 \pm 0.3$ & $16.3 \pm 1.1$ \\
\hline 1949 & $-14.7 \pm 0.5$ & $16.4 \pm 1.3$ \\
\hline 1950 & $-15.1 \pm 0.2$ & $15.9 \pm 0.4$ \\
\hline 1952 & $-14.9 \pm 0.1$ & $16.3 \pm 0.5$ \\
\hline 1953 & $-15.4 \pm 0.2$ & $16.6 \pm 1.1$ \\
\hline 1954 & $-14.8 \pm 0.3$ & $15.8 \pm 1.5$ \\
\hline 1955 & $-15.5 \pm 0.2$ & $15.6 \pm 1.3$ \\
\hline 1956 & $-15.3 \pm 0.4$ & $15.0 \pm 0.6$ \\
\hline 1957 & $-15.7 \pm 0.2$ & $14.7 \pm 0.3$ \\
\hline 1958 & $-15.4 \pm 0.3$ & $15.2 \pm 0.3$ \\
\hline 1959 & $-15.3 \pm 0.2$ & $15.0 \pm 0.5$ \\
\hline 1960 & $-15.2 \pm 0.2$ & $15.4 \pm 1.3$ \\
\hline 1961 & $-15.3 \pm 0.2$ & $14.9 \pm 0.8$ \\
\hline 1962 & $-15.4 \pm 0.3$ & $15.1 \pm 1.0$ \\
\hline 1964 & $-15.1 \pm 0.2$ & $14.9 \pm 1.0$ \\
\hline 1965 & $-15.5 \pm 0.5$ & $15.9 \pm 0.8$ \\
\hline 1966 & $-15.2 \pm 0.1$ & $15.7 \pm 1.2$ \\
\hline 1970 & $-15.2 \pm 0.2$ & $15.8 \pm 0.7$ \\
\hline 1971 & $-15.6 \pm 0.2$ & $16.3 \pm 1.2$ \\
\hline 1972 & $-15.3 \pm 0.3$ & $14.8 \pm 0.5$ \\
\hline 1973 & $-15.7 \pm 0.4$ & $16.4 \pm 0.7$ \\
\hline 1974 & $-15.5 \pm 0.3$ & $16.5 \pm 0.5$ \\
\hline 1975 & $-16.1 \pm 0.1$ & $15.5 \pm 1.0$ \\
\hline 1976 & $-15.5 \pm 0.2$ & $15.2 \pm 0.7$ \\
\hline 1977 & $-16.2 \pm 0.4$ & $15.1 \pm 0.8$ \\
\hline 1978 & $-15.9 \pm 0.3$ & $15.7 \pm 0.8$ \\
\hline 1979 & $-16.5 \pm 0.2$ & $14.9 \pm 0.6$ \\
\hline 1980 & $-16.0 \pm 0.2$ & $14.3 \pm 0.6$ \\
\hline 1981 & $-15.7 \pm 0.5$ & $15.7 \pm 1.0$ \\
\hline 1982 & $-15.6 \pm 0.6$ & $15.0 \pm 1.3$ \\
\hline 1983 & $-15.4 \pm 0.3$ & $15.5 \pm 1.1$ \\
\hline 1984 & $-15.7 \pm 0.1$ & $15.6 \pm 0.8$ \\
\hline 1985 & $-15.5 \pm 0.4$ & $15.6 \pm 0.5$ \\
\hline 1986 & $-15.8 \pm 0.4$ & $15.5 \pm 0.6$ \\
\hline 1991 & $-16.1 \pm 0.2$ & $15.9 \pm 0.6$ \\
\hline 1992 & $-15.9 \pm 0.3$ & $15.6 \pm 1.2$ \\
\hline 1993 & $-15.5 \pm 0.4$ & $16.9 \pm 0.6$ \\
\hline 1994 & $-15.6 \pm 0.1$ & $15.9 \pm 1.2$ \\
\hline 1995 & $-16.1 \pm 0.3$ & $15.0 \pm 1.5$ \\
\hline 1997 & $-15.7 \pm 0.3$ & $16.5 \pm 0.6$ \\
\hline 1999 & $-16.6 \pm 0.3$ & $15.1 \pm 1.2$ \\
\hline 2000 & $-16.5 \pm 0.3$ & $14.9 \pm 1.1$ \\
\hline Mean \pm SD & $-15.6 \pm 0.5$ & $15.6 \pm 1.0$ \\
\hline
\end{tabular}

\section{Interpretation}

Our time series shows a decline of $\sim 1.1 \%$ in mean $\delta^{13} \mathrm{C}$ for juvenile male northern fur seals foraging in the eastern Bering and western Gulf of Alaska from 1948 to 2000 (Fig. 1A). There are 4 possible explanations for this negative trend. First, as suggested by Schell (2000), a decrease in $\delta^{13} \mathrm{C}$ could be related to a decline in photosynthetic rate and primary production in the region over the past several decades. Second, the diet, and hence the $\delta^{13} \mathrm{C}$ values, of juvenile male Callorhinus ursinus diets may have shifted in response to changes in prey abundance and availability. Third, $\delta^{13} \mathrm{C}$ values of primary producers are known to vary spatially from east to west across the Bering Sea and Aleutian Island chain (Schell et al. 1998). Thus, if the foraging location of juvenile male $C$. ursinus changed systematically over the time interval in question, then it is possible that the $\delta^{13} \mathrm{C}$ value of ingested prey changed as well. Note that this explanation does not require that the relative frequency of prey types consumed by juvenile male fur seals changed over the past several decades. Lastly, the decrease in mean $\delta^{13} \mathrm{C}$ values may have been due to a decrease in the $\delta^{13} \mathrm{C}$ value of phytoplankton that had nothing to do with a drop in growth rate. The $\delta^{13} \mathrm{C}$ value of marine carbon reservoirs may drop in response to 2 distinct but additive anthropogenic effects: (1) the burning of isotopically 'light' fossil fuels, which decreases the $\delta^{13} \mathrm{C}$ value of surface ocean carbon reservoirs, and (2) increases in $\left[\mathrm{CO}_{2}\right]_{\mathrm{aq}}$ of the surface ocean, which increase the magnitude of carbon isotope fractionation during photosynthesis $\left(\varepsilon_{\mathrm{p}}\right)$. We examine each of these explanations in turn and, when possible, use additional data to constrain potential interpretations.

As mentioned above, Schell's (2000) explanation that a decrease in the $\delta^{13} \mathrm{C}$ bowhead baleen indicates a drop in primary production was based on experiments that illustrated a linear relationship between phytoplankton $\delta^{13} \mathrm{C}$ values and phytoplankton cell-growth rates, such that lower $\delta^{13} \mathrm{C}$ values signalled low cellular growth rates and (it is assumed) lower net primary production (Laws et al. 1995, Bidigare et al. 1997, Popp et al. 1998). Using simple relationships derived from growth rate experiments, the $2.7 \%$ drop in bowhead whale $\delta^{13} \mathrm{C}$ would correspond to an estimated decrease in seasonal carbon fixation of $\sim 30$ to $40 \%$ in the Bering Sea over the past 3 decades. Furthermore, modern bowhead $\delta^{13} \mathrm{C}$ values are significantly lower than those from archaeological samples, suggesting that marine

Table 2. Callorhinus ursinus. Mean $( \pm 1 \mathrm{SD}) \delta^{13} \mathrm{C}$ and $\delta^{15} \mathrm{~N}$ values of tooth dentin of juvenile male tooth dentin (GL3) binned by decade

\begin{tabular}{|cccc|}
\hline Time period & $\mathrm{n}$ & $\delta^{13} \mathrm{C}$ & $\delta^{15} \mathrm{~N}$ \\
\hline $1914-1915$ & 10 & $-15.0(0.4)$ & $17.6(1.3)$ \\
$1948-1959$ & 55 & $-15.2(0.4)$ & $15.7(1.1)$ \\
$1960-1969$ & 30 & $-15.3(0.3)$ & $15.3(1.0)$ \\
$1970-1979$ & 50 & $-15.8(0.5)$ & $15.6(0.9)$ \\
$1980-1989$ & 35 & $-15.7(0.4)$ & $15.3(0.9)$ \\
$1990-2000$ & 40 & $-16.0(0.5)$ & $15.7(1.2)$ \\
\hline
\end{tabular}


productivity is lower today than during the late Holocene ( 1500 yr BP; Schell 2000).

Other mechanisms, such as a significant decrease in plankton biomass or cell size with no associated change in cellular growth rates, could act to decrease food web $\delta^{13} \mathrm{C}$ values. Long-term estimates for plankton biomass in the North Pacific Ocean and eastern Bering Sea do show inter-decadal variations (Sugimoto \& Tadokoro 1998), but no significant long-term negative trend over the past 40 yr. Unfortunately, there are no direct estimates of phytoplankton cellular growth rates (seasonal or annual) in the eastern Bering Sea for the time period in question; thus we have to rely on indirect proxies to extrapolate long-term patterns in primary productivity. Nitrate is often a limiting nutrient in surface waters; thus a change in the concentration or uptake rates of $\mathrm{NO}_{3}$ over the past several decades might indicate that primary productivity has changed. A recent comparison of pre-bloom nitrate concentrations collected in the eastern Bering Sea demonstrated no significant differences from the 1970s to the 1990s (Whitledge 1999, Rho 2000). These studies, in conjunction with others focused on nitrogen cycling and sea ice dynamics (McRoy et al. 2001, Hunt et al. 2002) in this system, suggest no long-term decline in spring primary production over the past several decades.

The second potential explanation for the observed decline in GL3 $\delta^{13} \mathrm{C}$ values may be that the diet of juvenile male fur seals changed over the time interval in question. Fig. 2 presents the percent occurrence of common prey for 3 time periods obtained via gut content and scat studies in the southeastern Bering Sea and Pribilof Islands since 1960. Note that most dietary studies conducted between 1960 and 1990 focused on adult females, whereas data from 1992 to 2000 are derived from juvenile males. Diets of Callorhinus ursinus sampled during pelagic harvests between 1960 and 1974 (Fig. 2A; Kajimura 1984) were spread evenly over a number of taxa. Capelin and squid were more important than adult walleye pollock, whereas herring and eulachon were minor but variable prey sources. Data from the 1980s (Sinclair et al. 1994, Fig. 2B), obtained via gut content (i.e. pelagic harvests) and scat analysis, show that capelin and eulachon were no longer important prey items and that diets were dominated by juvenile walleye pollock. This pattern continued into the 1990s. The most recent diet data, collected from 1992 to 2000 on the Pribilof Islands via scat analysis, suggest that walleye pollock made up $\sim 70 \%$ of juvenile male fur seal diets, and sand lance, herring, and squid (genera Gonatopsis and Gonatus) were small $(<10 \%)$ dietary components (Antonelis et al. 1997; Ream 2005; Fig. 2C). Overall, after the 1960 to 1974 collections, fur seal diets shifted from adult ( $>2 \mathrm{yr}$

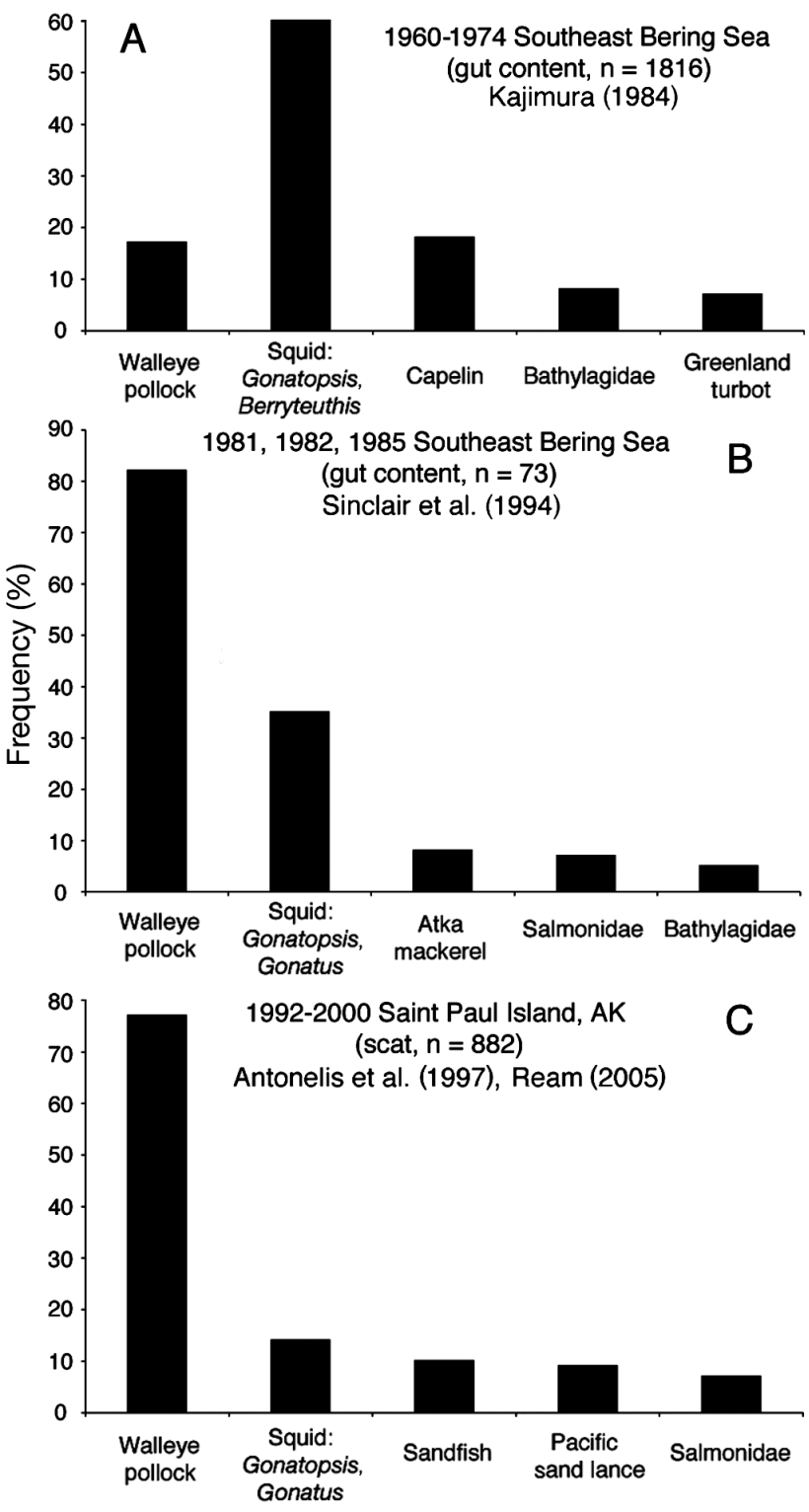

Fig. 2. Percent occurrence of most abundant Callorhinus ursinus prey items compiled from stomach content and scat analysis. (A) Stomach content data collected during pelagic harvests ( 90\% females) during August and September 1960 to 1974 ; (B) stomach content data collected during pelagic harvests in early $1980 \mathrm{~s}$; (C) data from juvenile male (2 to 5 yr) scats collected from Saint Paul Island during summer months

(June to October) 1992 to 2000. Data sources as given

old) to energetically less valuable juvenile walleye pollock, and the percent frequency of squid and capelin significantly decreased.

Isotope data of common Callorhinus ursinus prey items are sparse and geographically scattered, but present a general pattern that can be used in conjunction with the dietary data summarized above to assess the possibility that long-term changes in $C$. ursinus isotope values are driven by shifts in the type of prey 


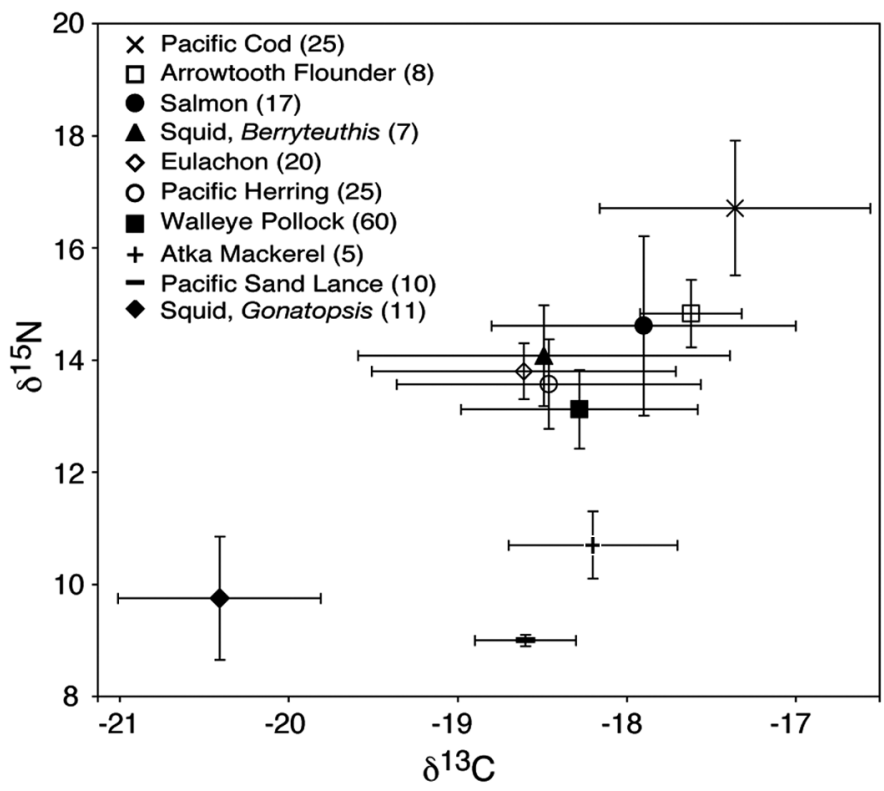

Fig. 3. Mean ( $\pm 1 \mathrm{SD}) \delta^{13} \mathrm{C}$ and $\delta^{15} \mathrm{~N}$ values of common Callorhinus ursinus whole prey items collected from western Gulf of Alaska, eastern Bering Sea, and Shelikof Strait (Kurle \& Worthy 2001, C. M. Kurle \& E. H. Sinclair unpubl. data). Pooled isotope data include values for a range of body sizes for each prey species. Nos. in parentheses: number of individuals analyzed

consumed. Fig. 3 presents mean $\delta^{13} \mathrm{C}$ and $\delta^{15} \mathrm{~N}$ values of common $C$. ursinus prey items collected in the southeastern Bering Sea, western Gulf of Alaska, and Shelikof Strait (Kurle \& Worthy 2001). The positive linear trend evident in Fig. 3 suggests that isotopic differences among prey species are primarily controlled by trophic level, which is strongly related to animal size in marine ecosystems. The slope of the trend is largely influenced by changes in $\delta^{15} \mathrm{~N} ; \delta^{15} \mathrm{~N}$ values increase by $\sim 3$ to $5 \%$ o whereas $\delta^{13} \mathrm{C}$ value only changes by $\sim 1 \%$ with each trophic step. Thus, if the $\sim 1.1 \%$ decrease in mean GL3 $\delta^{13} \mathrm{C}$ over the past 5 decades is largely due to a shift in prey type, or change in the trophic level of consumed prey, it should be accompanied by a significant drop in mean $\delta^{15} \mathrm{~N}$. Furthermore, the gut content and scat data summarized above suggest that squid, characterized by relatively low $\delta^{13} \mathrm{C}$ and $\delta^{15} \mathrm{~N}$ values (Fig. 3), have decreased in importance while the proportion of walleye pollock, characterized by comparatively high $\delta^{13} \mathrm{C}$ and $\delta^{15} \mathrm{~N}$, have increased in northern fur seal diets over the time interval in question. Thus, in the absence of simultaneous decreases in food web $\delta^{15} \mathrm{~N}$, the shift in diet implied by gut content and scat data should have led to an increase in C. ursinus $\delta^{13} \mathrm{C}$ and $\delta^{15} \mathrm{~N}$ values since the $1960 \mathrm{~s}$. However, mean GL3 $\delta^{15} \mathrm{~N}$ has not changed (Fig. 1B), while mean GL3 $\delta^{13} \mathrm{C}$ has dropped significantly (Fig. 1A).
A third possibility is that juvenile male Callorhinus ursinus systematically shifted their average annual foraging localities between 1948 and 2000. Carbon and nitrogen isotope values are known to vary spatially from east to west in the southern Bering Sea, such that average zooplankton and euphausid $\delta^{13} \mathrm{C}$ and $\delta^{15} \mathrm{~N}$ decrease by $\sim 1$ and $\sim 3 \%$ respectively across the continental shelf-slope break (Schell et al. 1998). Relatively low $\delta^{13} \mathrm{C}$ values of primary consumers from the deep waters of the southwestern Bering Sea are believed to be the result of phytoplankton growth rates, which are much lower here than in the continental shelf waters of the eastern Bering Sea. Differences in $\delta^{15} \mathrm{~N}$ values between primary consumers are most likely due to the extent of vertical mixing of the water column that acts to enhance or limit nutrient supply to the euphotic zone. Again, if the decrease in mean GL3 $\delta^{13} \mathrm{C}$ is attributable to a systematic westward shift in foraging location from 1948 to 2000 , then GL3 $\delta^{15} \mathrm{~N}$ should have decreased by $\sim 3 \%$, but no such trend is evident in the data (Fig. 1B).

Finally, Cullen et al. (2001) argued that a significant portion $(>50 \%)$ of the $\sim 2.7 \%$ o decrease in the $\delta^{13} \mathrm{C}$ of bowhead whale baleen reported by Schell (2000) resulted from 2 distinct but additive anthropogenic effects that impact phytoplankton at the base of marine food webs. They estimated the expected change in carbon isotope composition of phytoplankton $\left(\Delta^{13} C_{p}\right)$ due to anthropogenic influences as the sum of the effect of increasing atmospheric $\mathrm{pCO}_{2}$ on (1) the $\delta^{13} \mathrm{C}$ composition of aqueous $\mathrm{CO}_{2}\left(\Delta^{13} \mathrm{C}_{\mathrm{aq}}\right)$ and (2) the carbon isotopic fractionation by marine phytoplankton $\left(\Delta \varepsilon_{\mathrm{p}}\right)$. Previously published rates were used to estimate $\Delta \delta^{13} \mathrm{C}_{\mathrm{aq}}$ or the Suess effect, resulting from an influx of isotopically 'light' carbon via the burning of fossil fuels (Quay et al. 1992, Francey et al. 1999). The Suess effect's influence on $\Delta \delta^{13} \mathrm{C}_{\mathrm{p}}$ is relatively small, approximately -0.1 to $-0.2 \%$ per decade (Quay et al. 1992, Sonnerup et al. 1999). To calculate the effects of increasing $\left[\mathrm{CO}_{2}\right]_{\mathrm{aq}}$ on carbon isotope fractionation in marine phytoplankton, Cullen et al. (2001) estimated an increase in surface water $\left[\mathrm{CO}_{2}\right]_{\mathrm{aq}}$ of $\sim 2.3 \mu \mathrm{m}$ from 1966 to 1997 , while assuming a constant mean annual surface temperature and species composition of phytoplankton stocks. Over the 230 yr period (1966 to 1997) examined by Schell (2000), such an increase in $\left[\mathrm{CO}_{2}\right]_{\mathrm{aq}}$ concentrations would result in a change in $\Delta \varepsilon_{\mathrm{p}}$ of $-1.1 \pm$ $0.5 \%$. When combined with conservative estimates of the Suess effect, total $\Delta \delta^{13} \mathrm{C}_{\mathrm{p}}$ is estimated to have been $-1.4 \pm 0.5 \%$ from 1966 to 1997 , or $\sim 0.046 \% \mathrm{yr}^{-1}$ over the 31 yr time period.

Schell (2001) countered that the anthropogenic effects cited by Cullen et al. (2001) have smaller impacts than these authors estimate in high latitude regions such as the Bering Sea, because deep winter mixing of surface waters results in greater dilution of atmospheric 
inputs. Published data on $\Delta^{14} \mathrm{C}$ of dissolved inorganic carbon (DIC), chloroflurocarbons, and DIC $\delta^{13} \mathrm{C}$ suggest that anthropogenic influxes at high latitudes in the North Pacific and Bering Sea $\left(>50^{\circ} \mathrm{N}\right)$ are being diluted to a greater extent than those at lower latitudes (Quay et al. 1992, Warner \& Roden 1995). Schell (2001) presented $\delta^{15} \mathrm{~N}$ data from the baleen time series to argue for a perturbation in nitrogen dynamics but, as noted earlier, concerns remain about shifts in bowhead migration and the limited number of individuals used to construct the critical early portion of the nitrogen isotope time series. Second, bowhead whales are often observed foraging along sea ice margins during their spring/fall migrations into the Beaufort Sea and wintering grounds in the western Bering Sea. The effects of sea ice on the $\delta^{13} \mathrm{C}$ values of associated primary producers is poorly resolved; however, historical decreases in the sea ice extent may contribute to a longterm decline in food web $\delta^{13} \mathrm{C}$ since primary producers that grow in sea ice are likely to have higher carbon isotope values than pelagic phytoplankton.

The systematic long-term decrease in $\delta^{13} \mathrm{C}$ in juvenile male Callorhinus ursinus of $\sim 1.1$ or $0.0215 \%$ o $\mathrm{yr}^{-1}$ over the past 5 decades (1948 to 2000) is supported by data from more than 200 individuals. The removal of confounding factors related to age, sex, and locality bolster our confidence in the magnitude of the signal. The magnitude and the timing of the decline suggest that the drop results from the anthropogenic factors cited by Cullen et al. (2001). The change in mean GL3 $\delta^{13} \mathrm{C}$ is substantially lower than the total change in $\Delta \delta^{13} \mathrm{C}_{\mathrm{p}}$ due to anthropogenic factors estimated by Cullen et al. (2001), especially if calculations are extrapolated to cover the previous 5 decades instead of the $31 \mathrm{yr}$ time period focused on by Schell (2000) and Cullen et al. (2001). We recognize that a shift in diet composition to higher trophic level prey (as implied by gut content and scat analysis) would cause dietary $\delta^{13} \mathrm{C}$ to rise, which might partially offset longterm $\delta^{13} C_{p}$ declines due to anthropogenic inputs. However, as noted before, the lack of a trend in the $\delta^{15} \mathrm{~N}$ time series does not support a strong increase in the dietary trophic level of C. ursinus. Like Schell (2001), we suggest that anthropogenic effects will be diluted to a much greater extent at high latitudes $\left(>50^{\circ} \mathrm{N}\right)$ and that Cullen et al. (2001) overestimated $\Delta \delta^{13} \mathrm{C}_{\mathrm{p}}$ for these systems. Thus, the significant linear decline in GL3 $\delta^{13} \mathrm{C}$ (Fig. 1A) was most likely due to anthropogenic inputs, but the magnitude of the decline suggests that dilution effects are important in high-latitude systems such as the North Pacific and eastern Bering Sea.

\section{Short-term shifts}

Data

The simple linear regression fit to the mean annual $\delta^{13} \mathrm{C}$ values in Fig. 1A masks a considerable amount of temporal variability in the 1948 to 2000 time series. To assess the residual variability attributable to shortterm shifts in the time series, we de-trended the annual mean $\delta^{13} \mathrm{C}$ data using the slope $\left(-0.0215 \% \mathrm{yr}^{-1}\right)$ of the linear regression. The de-trended $\delta^{13} \mathrm{C}$ time series is presented in Fig. 4A. We then applied several func-

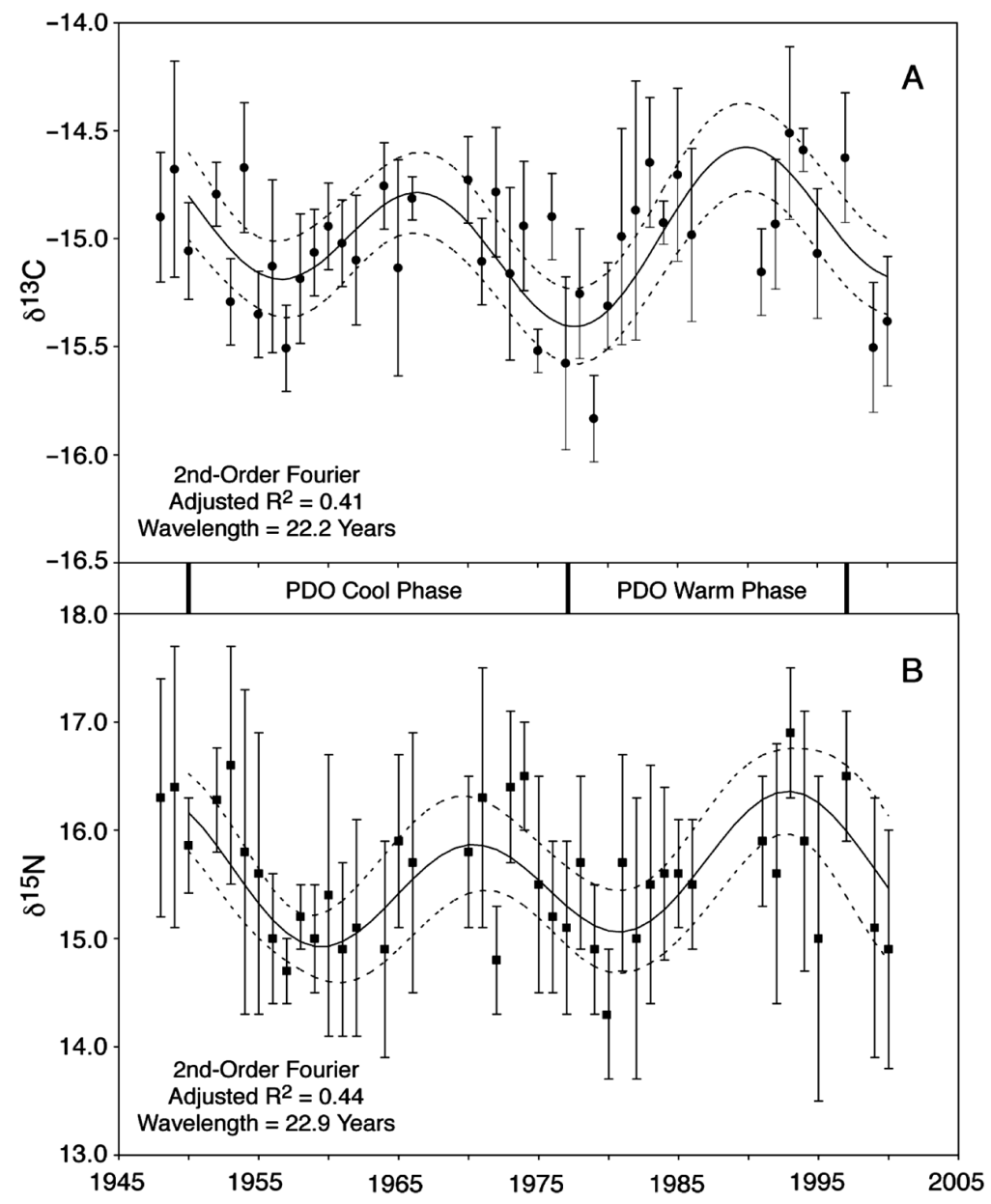

Fig. 4. Callorhinus ursinus. Mean $( \pm 1 \mathrm{SD})$ annual values of $(\mathrm{A}) \delta^{13} \mathrm{C}$ and (B) $\delta^{15} \mathrm{~N}$ in tooth dentin of juvenile males (GL3). $\delta^{13} \mathrm{C}$ time series has been detrended using linear regression in Fig. 1. No correction has been applied to $\delta^{15} \mathrm{~N}$ time series. Continuous lines: 2nd-order Fourier model which provided best fit for both carbon and nitrogen isotope data sets (Table 3); dashed lines: $95 \%$ confidence intervals for modeled fit. Adjusted $\mathrm{R}^{2}$ values and model frequencies are shown for each data set. PDO: Pacific Decadal Oscillation 
Table 3. Callorhinus ursinus. Statistics for various model fits (5th order polynomial and 2nd order Fourier) for mean annual $\delta^{13} \mathrm{C}$ and $\delta^{15} \mathrm{~N}$ time series data presented in Fig. 4. Least squares error of fit (SSE), $\mathrm{R}^{2}$, adjusted $\mathrm{R}^{2}$, and root mean square error (RMSE) are shown for each model fit. Fourier: model fit presented in Fig. 4

\begin{tabular}{|llrcrr|}
\hline Model fit & Data Set & SSE & $\mathrm{R}^{2}$ & Adj. R & RMSE \\
\hline Linear & Carbon & 100.4 & 0.01 & -0.02 & 1.58 \\
Polynomial & Carbon & 66.5 & 0.34 & 0.25 & 1.36 \\
Fourier & Carbon & $\mathbf{5 2 . 7}$ & $\mathbf{0 . 4 8}$ & $\mathbf{0 . 4 1}$ & $\mathbf{1 . 2 1}$ \\
Linear & Nitrogen & 38.1 & 0.05 & 0.02 & 0.98 \\
Polynomial & Nitrogen & 24.2 & 0.40 & 0.31 & 0.82 \\
Fourier & Nitrogen & $\mathbf{1 9 . 6}$ & $\mathbf{0 . 5 1}$ & $\mathbf{0 . 4 4}$ & $\mathbf{0 . 7 4}$ \\
\hline
\end{tabular}

tions to the de-trended data to characterize the shortterm shifts evident in the time series, including a simple linear regression, 5th order polynomial, and 2nd order Fourier series (Table 3). For the $\delta^{13} \mathrm{C}$ time series, the 2nd order Fourier series model yields an adjusted $\mathrm{R}^{2}$ value of 0.41 (Fig. 4A), with a wavelength of $22.2 \mathrm{yr}^{-1}$. Furthermore, this model suggests that $\delta^{13} \mathrm{C}$ values were low in the early 1950s, late 1970s, and late 1990s, with concomitant maxima in $\delta^{13} \mathrm{C}$ from 1965 to 1975 and 1985 to 1995.

For the $\delta^{15} \mathrm{~N}$ time series, no long-term correction was needed (Fig. 4B). Again, we applied several functions to the mean annual $\delta^{15} \mathrm{~N}$ time series to characterize the short-term shifts evident in the record (Table 3). Similar to the $\delta^{13} \mathrm{C}$ data, a 2 nd order Fourier series yields a fit with the highest adjusted $\mathrm{R}^{2}$ value (0.44; Fig. 4B). The wavelength for the $\delta^{15} \mathrm{~N}$ Fourier model $(22.9 \mathrm{yr}$, $95 \% \mathrm{CI}=20.8$ to $25.5 \mathrm{yr}$ ) is indistinguishable from the wavelength for the $\delta^{13} \mathrm{C}$ Fourier model $(22.2 \mathrm{yr}$, $95 \% \mathrm{CI}=20.6$ to $24.1 \mathrm{yr}$ ). The $\delta^{15} \mathrm{~N}$ Fourier series, however, seems to be slightly out of phase with the $\delta^{13} \mathrm{C}$ series, lagging the $\delta^{13} \mathrm{C}$ Fourier series by $\sim 3$ to $5 \mathrm{yr}$.

\section{Interpretation}

Several previous studies have cited the importance of short-term climatic events in reducing the quantity and/or quality of key prey species to marine mammals (Francis \& Heath 1991, Trillmich \& Dellinger 1991, Melin et al. 2003). Inter-annual climate and oceanographic variability in the northeast Pacific Ocean is linked to the PDO and ENSO (Mantua et al. 1997, McGowan et al. 1998, Chavez et al. 2001). PDO cycles occur at $\sim 20$ to $30 \mathrm{yr}$ time intervals, whereas ENSO events recur at 2 to $10 \mathrm{yr}$ intervals. The PDO refers to large-scale changes in North Pacific sea surface temperatures that oscillate between a warm and a cool phase. Instrumental data show evidence of 2 full cycles over the past century with warm phases occur- ring from 1925-1950 and 1977-1997; cool phases occurred between $\sim 1900-1925$ and $\sim 1950-1977$. Time series of a variety of physical and biological oceanographic data show fluctuations on this same time scale; however, PDO forcing mechanisms are poorly understood. Furthermore, since individual physical and/or biological parameters are likely to be influenced by mechanisms that operate on independent time scales, PDO indices often show differences in the absolute timing of phase shifts, the relative rate at which shifts occur, and the overall duration of each phase. In regard to Callorhinus ursinus prey availability and foraging behavior, the 1977 regime shift is known to have negatively influenced the recruitment of some fish stocks in the North Pacific, including salmon, hake, and herring (Beamish \& Bouillon 1993, Francis \& Hare 1994, Mantua et al. 1997), all of which represent relatively minor $(\leq 10 \%)$ dietary components (Kajimura 1984, Sinclair et al. 1994, Antonelis et al. 1997, Ream 2005) of $C$. ursinus' diet.

Both the $\delta^{13} \mathrm{C}$ and $\delta^{15} \mathrm{~N}$ GL3 time series recorded oscillations with a wavelength of $\sim 20$ to $25 \mathrm{yr}$, which is similar to the average duration of observed PDO warm or cold phases in the northeast Pacific Ocean (Fig. 4). Minima in $\delta^{13} \mathrm{C}$ and $\delta^{15} \mathrm{~N}$ values in the GL3 time series occur at approximately the same time as shifts from warm to cool or cool to warm phases in various PDO indices but there is no systematic relationship between warm (or cold) phases and GL3 carbon or nitrogen isotope values. For reasons discussed in detail above, oscillations in the GL3 time series could be caused by systematic changes in juvenile Callorhinus ursinus foraging behavior or baseline shifts in the isotopic composition of primary producers over time. Again, the relative abundance of major $C$. ursinus prey items (i.e. squid, walleye pollock) is not known to have varied on a cyclical basis over the time period in question. Modeling suggests that $C$. ursinus had a relatively small top-down impact on walleye pollock biomass from 1979 to 1993 in comparison to other pelagic predators; hence subtle fluctuations in overall walleye pollock abundance may not influence its availability to C. ursinus (Livingston \& Jurado-Molina 2000). Recent research examining the oceanographic factors responsible for walleye pollock recruitment offers promise in the ability to model historic stock size from environmental data in the eastern Bering Sea (Porter et al. 2005, Mueter et al. 2006).

At present, it is poorly understood how changes in physical and biological parameters of the Bering Sea system influence isotope values at the base of the food web. If the GL3 record primarily reflects changes in phytoplankton growth rates over time, it is unlikely that shifts in primary producer growth rates, and hence their $\delta^{13} \mathrm{C}$ values, are driven by changes in the 
nitrogen dynamics of the system (i.e. $\mathrm{NO}_{3}$ availability) because shifts in the GL3 $\delta^{15} \mathrm{~N}$ record trail those in the $\delta^{13} \mathrm{C}$ time series by $\sim 3$ to $5 \mathrm{yr}$. While the cyclical nature of the GL3 time series suggests a bottom-up control, the scarcity of multi-annual isotopic records for primary producers or consumers make it difficult to constrain potential driving mechanisms at this time. The influence of sea ice extent and the relative timing of the spring ice retreat on primary producer isotope values is a relatively unexplored yet intriguing topic, as these factors are known to strongly influence recruitment further up the food chain.

Our data show no clear relationship between ENSO events and Callorhinus ursinus foraging behavior and/ or changes in oceanographic conditions. To date, no studies have linked the foraging success or short-term shifts in population estimates of Pribilof Island C. ursinus to ENSO events, which are known to have negative effects on $C$. ursinus pup survival and female recruitment at temperate latitudes within the California Current (Melin et al. 2003).

\section{Mean isotope values of juvenile male Callorhinus ursinus}

\section{Data}

Mean $\left( \pm 1\right.$ SD) GL3 $\delta^{13} \mathrm{C}$ and $\delta^{15} \mathrm{~N}$ values averaged over the entire 1948 to 2000 time series were $-15.6 \pm$ $0.5 \%$ and $15.6 \pm 1.0 \%$ respectively (Table 4 ). Before comparing mean GL3 $\delta^{13} \mathrm{C}$ values to previously published carbon isotope values for adult Callorhinus ursinus males and females, we must take into account historic decreases in the isotopic composition of surface ocean carbon reservoirs due to anthropogenic inputs. For the juvenile males, we will use the mean of the detrended $\delta^{13} \mathrm{C}$ time series $(-15.0 \pm 0.5 \%$ ) for comparison with previously published isotope values of adult males and females (Burton \& Koch 1999) from the Pribilof Islands. We have corrected previously published

Table 4. Callorhinus ursinus. Mean $( \pm 1 \mathrm{SD}) \delta^{13} \mathrm{C}$ and $\delta^{15} \mathrm{~N}$ values of bone collagen of adult males and females (data from Burton \& Koch 1999) and tooth dentin collagen of juveniles males (GL3) from Pribilof Islands. All $\delta^{13} \mathrm{C}$ data, including previously published values for adult males and females, have been corrected for anthropogenic effects using the linear relationship shown in Fig. 1 and the collection year for each specimen

\begin{tabular}{|lrcc|}
\hline Age Class & \multicolumn{1}{c}{$\mathrm{n}$} & $\delta^{13} \mathrm{C}$ & $\delta^{15} \mathrm{~N}$ \\
\hline Adult males $^{\mathrm{a}}$ & 9 & $-14.9(0.9)$ & $17.4(2.1)$ \\
Adult females $^{\mathrm{a}}$ & 10 & $-14.2(0.7)$ & $16.6(1.4)$ \\
Juv. males (1948-2000) & 210 & $-15.0(0.5)$ & $15.6(1.0)$ \\
aData from Burton \& Koch (1999) & & \\
\hline
\end{tabular}

values for adult males and females using the linear relationship presented in the present Fig. 1 and the year of collection for each specimen. GL3 $\delta^{13} \mathrm{C}$ values are statistically indistinguishable from previously published values for adult males, but significantly lower than mean values for adult females (Tukey's, $\mathrm{p}<0.05$ ). GL3 $\delta^{15} \mathrm{~N}$ values are significantly different from previously published adult female and male values (Tukey's, p < 0.05).

Interpretation

Recent satellite tracking data show that parturient adult female and juvenile male northern fur seals exploit a wide range of oceanic habitats in the Bering Sea during the breeding season, from inner shelf (<50 m water depth) to off-shelf ( $3000 \mathrm{~m}$ water depth) environments, and that there is geographical separation of foraging habitat during the breeding season (June to November) among females from different colonies on the Pribilof Islands (Robson et al. 2004, Sterling \& Ream 2004). Unfortunately, little is known about where young-of-the-year (YOY) and juvenile Callorhinus ursinus forage outside the breeding season. Adult females from the Pribilofs are known to exploit northeast Pacific offshore pelagic habitats as far south as southern California outside the breeding season (Kajimura 1984), and tracking data suggests that the North Pacific sub-arctic convergence provides important foraging habitat during the winter (Ream et al. 2005). While it is likely that $C$. ursinus YOY and juveniles forage in similar localities as adult females outside the breeding season, no satellite data exists to confirm this hypothesis.

As noted above, the $\delta^{13} \mathrm{C}$ and $\delta^{15} \mathrm{~N}$ values of primary producers vary spatially from east to west across the Bering Sea (Schell et al. 1998). $\delta^{13} \mathrm{C}$ and $\delta^{15} \mathrm{~N}$, as measured at the base of the food web, also vary with latitude. For example, recent studies suggest a $\sim 2$ to $3 \%$ decrease in the nitrogen and carbon isotope values of primary producers from temperate latitude $(\sim 30$ to $40^{\circ} \mathrm{N}$ ) to high-latitude $\left(>50^{\circ} \mathrm{N}\right.$ ) ecosystems (Saino \& Hattori 1987, Goericke \& Fry 1994, Altabet et al. 1999, Rau et al. 2001). These spatial patterns in isotope values of primary producers and consumers have been used to approximate foraging latitude among various northeast Pacific pinnipeds (Burton \& Koch 1999, Burton et al. 2001, Aurioles-Gamboa et al. 2006).

$\delta^{13} \mathrm{C}$ values of juvenile $3 \mathrm{yr}$ old northern fur seal males are significantly lower $(\sim 1 \%)$ than those of adult females and statistically indistinguishable from those of adult males (Burton \& Koch 1999). The $\delta^{15} \mathrm{~N}$ values of juvenile Callorhinus ursinus are significantly lower than those of both adult female and male values by 
$\sim 1$ and $2 \%$ respectively (Burton \& Koch 1999). In addition to the spatial differences in isotope values of primary producers discussed above, it is important to consider age related differences in trophic level. Since 3 yr old males are approximately the same size as adult females (Gentry 1998) and since size strongly correlates with trophic position in pelagic marine ecosystems, these 2 age groups likely feed at approximately the same trophic level. Thus, the difference of $\sim 1 \%$ in both $\delta^{13} \mathrm{C}$ and $\delta^{15} \mathrm{~N}$ mean values between adult females and juvenile males suggest that male $C$. ursinus forage at higher latitudes than adult females outside the breeding season. This is supported by previous research that found juvenile males have lower skin $\delta^{13} \mathrm{C}$ and $\delta^{15} \mathrm{~N}$ values than adult females (Kurle \& Worthy 2001).

Comparison of juvenile and adult male values suggest that these age groups forage at similar latitudes but that adult males feed at a higher trophic level, since they are approximately 3 times as large as 3 yr old juvenile males (Gentry 1998). $\delta^{15} \mathrm{~N}$ values are more strongly influenced by trophic level than $\delta^{13} \mathrm{C}$ values by a factor of 3 (Michener \& Schell 1994), so subtle differences in trophic level may be detectable in nitrogen but not carbon isotope values. Likewise, if the significant difference in mean $\delta^{15} \mathrm{~N}$ between juvenile and adult males were due to longitudinal differences in foraging location (i.e. juvenile males forage further west than adult males), then adult males would also have higher mean $\delta^{13} \mathrm{C}$ values than juvenile males; yet juvenile and adult male $\delta^{13} \mathrm{C}$ values are statistically indistinguishable.

These comparisons suggest that 3 yr old juvenile males forage at similar latitudes but at a lower trophic level than adult males outside the breeding season. Our results suggest that juvenile male Callorhinus ursinus do not migrate as far south as adult females during the winter months, but likely use a combination of North Pacific habitats, including the western Gulf of Alaska and southern Bering Sea outside the breeding season.

\section{CONCLUSIONS}

Our data confirm that $\delta^{13} \mathrm{C}$ values did decrease in eastern Bering Sea and North Pacific food webs over the past several decades. The magnitude of the drop seen in our records is most consistent with the effects on oceanic phytoplankton expected in response to increasing concentrations of ${ }^{13} \mathrm{C}$-depleted atmospheric $\mathrm{CO}_{2}$ due to fossil fuel burning, tempered by strong vertical mixing in these high-latitude oceanic systems. The relative timing of $\delta^{13} \mathrm{C}$ and $\delta^{15} \mathrm{~N}$ minima in our time series is consistent with observed phase shifts in the
PDO. However, there is no systematic relationship between GL3 isotope values and warm (or cold) phases of the PDO, as the frequency of $\delta^{13} \mathrm{C}$ and $\delta^{15} \mathrm{~N}$ variations in the Callorhinus ursinus times series is approximately half as long as the frequency of the PDO. At present, it is difficult to assess whether the small amplitude oscillations present in the GL3 time series are driven by changes in oceanographic conditions associated with the PDO, as few historic isotopic records are available at any level of the pelagic food chain in the North Pacific Ocean. Furthermore, the physical and biological factors that influence isotope values in pelagic foodwebs are poorly resolved and operate on multiple time scales and may not act in concert with observed shifts in oceanographic parameters used to construct PDO indices. Finally, mean isotope values are consistent with juvenile males establishing their own migration patterns by Age 3. They no longer migrate south along with adult females and younger juveniles, but rather remain in the southern Bering Sea and/or western Gulf of Alaska during the winter months. However, juvenile males do not appear to forage at the same trophic level as adult males.

Acknowledgements. Access to and assistance in procuring Callorhinus ursinus tooth specimens was given by B. DeLong, T. Loughlin, T. Gelatt, and J. Thomason (NMML), and by J. Mead, C. Potter, and D. Allen (Smithsonian). We also thank E. Krivak-Tetley for assistance with the Merchantek micromill system. This research was partially funded through student research grants from the Myers Oceanographic and Marine Biology Trust, UCSC Long Marine Laboratory, and PADI Foundation.

\section{LITERATURE CITED}

Altabet MA, Pilskal C, Thunell R, Pride C, Sigman D, Chavez F, Francois R (1999) The nitrogen isotope biogeochemistry of sinking particles from the margin of the Eastern North Pacific. Deep-Sea Res I 46:655-679

Ambrose SH (1990) Preparation and characterization of bone and tooth collagen for isotopic analysis. J Archaeol Sci $17: 431-451$

Antonelis GA, Sinclair EH, Ream RR, Robson BW (1997) Interisland variation in the diet of female northern fur seals (Callorhinus ursinus) in the Bering Sea. J Zool 242: 435-451

Aurioles-Gamboa GD, Koch PL, Le Boeuf BJ (2006) Differences in foraging location of Mexican and California elephant seals: evidence from stable isotopes in pups. Mar Mamm Sci 22:326-338

Baker JD (1991) Trends in female northern fur seal, Callorhinus ursinus, feeding cycles indicated by nursing lines in juvenile male teeth. Masters thesis, University of Washington, Seattle, WA

Beamish RJ, Bouillon DR (1993) Pacific salmon production trends in relation to climate. Can J Fish Aquat Sci 50: 1002-1016

Bengston JL (1988) Long-term trends in the foraging patterns of female Antarctic fur seals at South Georgia. In: Sahr- 
hage D (ed) Antarctic Ocean and resources variability. Springer-Verlag, Berlin, p 286-291

Bidigare RR, Fluegge A, Freeman KH (1997) Consistent fractionation of ${ }^{13} \mathrm{C}$ in nature and in the laboratory: growth rate effects in some haptophyte algae. Global Biogeochem Cycles 11:279-292

Bigg MA (1990) Migration of northern fur seals (Callorhinus ursinus) off western North America. Can Tech Rep Fish Aquat Sci 1764, Nanaimo

Bigg MA, Fawcett I (1985) Two biases in diet determination of northern fur seals (Callorhinus ursinus). In: Beverton RH, Lavigne DM (eds) Marine mammals and fisheries. George Allen and Unwin, London, p 284-299

Burton RK, Koch PL (1999) Isotopic tracking of foraging and long-distance migration in northeastern Pacific pinnipeds. Oecologia 119:578-585

Burton RK, Snodgrass JJ, Gifford-Gonzalez D, Guilderson T, Brown T, Koch PL (2001) Holocene changes in the ecology of northern fur seals: insights from stable isotopes and archaeofauna. Oecologia 128:107-115

Chavez FP, Ryan J, Lluch-Cota SE, Niquen M (2001) From anchovies to sardines and back: multidecadal change in the Pacific Ocean. Science 299:217-221

Cullen JT, Rosenthal Y, Falkowski PG (2001) The effect of anthropogenic $\mathrm{CO}_{2}$ on the carbon isotope composition of marine phytoplankton. Limnol Oceanogr 46:996-998

DeNiro MJ, Epstein S (1978) Influence of diet on the distribution of carbon isotopes in animals. Geochim Cosmochim Acta 42:495-506

DeNiro MJ, Epstein S (1981) Influence of diet on the distribution of nitrogen isotopes in animals. Geochim Cosmochim Acta 45:341-351

Dobush GR, Ankney CD, Krementz DG (1985) The effect of apparatus, extraction time, and solvent type on lipid extractions of snow geese. Can J Zool 63:1917-1920

Ebbesmeyer CC, Cayan DR, Milan DR, Nichols FH, Peterson DH, Redmond KT (1991) 1976 step in the Pacific climate; forty environmental changes between 1968-1975 and 1977-1984. In: Betancourt JL, Tharp VL (eds) Proceedings of the Seventh Annual Climate (PACLIM) Workshop, April 1990. California Department of Water Resources, Interagency Ecological Studies Program Tech Rep 26, Sacramento, CA, p 115-126

Francey RJ, Allison CE, Etheridge DM, Trudinger CM and 5 others (1999) A 1000-year high precision record of delta C-13 in atmospheric CO². Tellus B 51:170-193

Francis RC, Hare SR (1994) Decadal-scale regime shifts in the large marine ecosystems of the Northeast Pacific; a case for historical science. Fish Oceanogr 3:279-291

Francis JM, Heath CB (1991) Population abundance, pup mortality, and copulation frequency in the California sea lion in relation to the 1983 El Niño on San Nicolas Island. In: Trillmich F, Ono KA (eds) Pinnipeds and El Niño: responses to environmental stress, Springer-Verlag, Berlin, p 119-128

Gentry RL (1998) Behavior and ecology of the northern fur seal. Princeton University Press, Princeton, NJ

Goericke R, Fry B (1994) Variations of marine plankton $\delta^{13} \mathrm{C}$ with latitude, temperature, and dissolved $\mathrm{CO}_{2}$ in the world ocean. Global Biochem Cycles 8:85-90

Hirons AC, Schell DM, Finney BP (2001) Temporal record of $\delta^{13} \mathrm{C}$ and $\delta^{15} \mathrm{~N}$ in North Pacific pinnipeds: inferences regarding environmental change and diet. Oecologia 129: 591-601

Hobson KA, Sease JL (1998) Stable isotope analyses of tooth annuli reveal temporal dietary records: an example using Steller sea lions. Mar Mamm Sci 14:116-129
Hobson KA, Sease JL, Merrick RL, Piatt JF (1997) Investigating trophic relationships of pinnipeds in Alaska and Washington using stable isotope ratios of nitrogen and carbon. Mar Mamm Sci 13:114-132

Hobson KA, Sinclair EH, York AE, Thomason JR, Merrick RE (2004) Retrospective isotopic analyses of Steller sea lion tooth annuli and seabird feathers: a cross-taxa approach to investigating regime and dietary shifts in the Gulf of Alaska. Mar Mamm Sci 20:621-638

Hunt GL, Stabeno P, Walters G, Sinclair E, Brodeur RD, Napp JM, Bond NA (2002) Climate change and control of the southeastern Bering Sea pelagic ecosystem. Deep-Sea Res II 49:5821-5853

Kajimura H (1984) Opportunistic feeding of the northern fur seal, Callorhinus ursinus, in the eastern North Pacific Ocean and eastern Bering Sea. NOAA Tech Rep NMFS SSRF-779, Seattle, WA

Kurle CM, Sinclair EH (2003) Estimation of Steller sea lion (Eumetopias jubatus) foraging ecology using stable nitrogen and carbon isotope ratio analyses of blood components. Abstract, Marine Mammal Biennial Symposium, Greensboro, NC

Kurle CM, Worthy GAJ (2001) Stable isotope assessment of temporal and geographic differences in feeding ecology of northern fur seals (Callorhinus ursinus) and their prey. Oecologia 126:254-265

Laws EA, Popp BN, Bidigare RR, Kennicutt MC, Macko SA (1995) Dependence of phytoplankton carbon isotopic -composition on growth rate and $\left[\mathrm{CO}_{2}\right]_{\mathrm{aq}}$-theoretical considerations and experimental results. Geochim Cosmochim Acta 59:1131-1138

Livingston PA, Jurado-Molina J (2000) A multispecies virtual population analysis of the eastern Bering Sea. ICES J Mar Sci 57:294-299

Mantua NJ, Hare SR, Zhang Y, Wallace JM, Francis RC (1997) A Pacific interdecadal climate oscillation with impacts on salmon production. Bull Am Meteorol Soc 78:1069-1079

McGowan JA, Cayan DR, Dorman LM (1998) Climate-ocean variability and ecosystem response in the northeast Pacific. Science 281:210-217

McRoy CP, Mizobata K, Nakanishi S, Saino S (2001) Trends in ocean conditions and new production on the shelf of the southeastern Bering Sea over the past twenty years. PICES Annual Meeting, Victoria, BC

Melin SR, DeLong RL, Orr AJ (2003) The status of the northern fur seal population at San Miguel Island California, in 2000 and 2001. In: Robson BW (ed) Fur seal investigations, 2000-2001. US Department of Commerce, Seattle, WA, p 51-58

Michener RH, Schell DM (1994) Stable isotope ratios as tracers in marine aquatic food webs. In: Lajtha $\mathrm{K}$, Michener $\mathrm{RH}$ (eds) Stable isotopes in ecology and environmental science. Blackwell Scientific Publications, Boston, p 138-157

Minagawa M, Wada E (1984) Stepwise enrichment of ${ }^{15} \mathrm{~N}$ along food chains: further evidence and the relation between $\delta^{15} \mathrm{~N}$ and animal age. Geochim Cosmochim Acta 48:1135-1140

Mueter FJ, Ladd C, Palmer MC, Norcross BL (2006) Bottomup and top-down controls of walleye pollock (Theragra chalcogramma) on the Eastern Bering Sea shelf. Prog Oceanogr 68:152-183

National Marine Fisheries Service (1993) Final conservation plan for the northern fur seal (Callorhinus ursinus). Prepared by the National Marine Mammal Laboratory/Alaska Fisheries Science Center, Seattle, Washington, and the Office of Protected Resources/National Marine Fisheries Service, Silver Spring, MD 
National Research Council (2002) The decline of the Steller sea lion in Alaskan waters: untangling food webs and fishing nets. Committee on the Alaska Groundfish Fishery and Steller Sea Lions. National Academy Press, Washington, DC

Newsome SD, Etnier MA, Aurioles-Gamboa D, Koch PL (2006) Using carbon and nitrogen isotope values to investigate maternal strategies in northeast Pacific otariids. Mar Mamm Sci 22:1-18

Ostrom PH, Lien J, Macko SA (1993) Evaluation of the diet of Sowerby's beaked whale, Mesoplodon bidens, based on isotopic comparisons among northwestern Atlantic cetaceans. Can J Zool 71:858-861

Perrin WF, Wursig B, Thewissen JGM (2002) Encyclopedia of marine mammals. Academic Press, San Diego, CA

Popp BN, Laws AE, Bidigare RR, Dore JE, Hanson KL, Wakeham SG (1998) Effect of phytoplankton cell geometry on carbon isotopic fractionation. Geochim Cosmochim Acta 62:69-77

Porter SM, Ciannelli L, Hillgruber N, Bailey KM, Chan KS, Canino MF, Haldorson LJ (2005) Environmental factors influencing larval walleye pollock (Theragra chalcogramma) feeding in Alaskan waters. Mar Ecol Prog Ser 302:207-217

Quay PD, Tilbrook B, Wong CS (1992) Oceanic uptake of fossil fuel $\mathrm{CO}_{2}-{ }^{13} \mathrm{C}$ evidence. Science 256:74-79

Rau GH, Chavez FP, Friederich GE (2001) Plankton ${ }^{13} \mathrm{C} /{ }^{12} \mathrm{C}$ variations in Monterey Bay, California: evidence of nondiffusive inorganic carbon uptake by phytoplankton in an upwelling environment. Deep-Sea Res I 48:79-94

Ream RR (2005) Northern fur seal status and life history overview. Pribilof Islands Collaborative Northern Fur Seal Meeting, January 28-30, Anchorage, AK

Ream RR, Sterling JT, Loughlin TR (2005) Oceanographic features related to northern fur seal migratory movements. Deep-Sea Res II 52:823-843

Rho T (2000) Carbon and nitrogen uptake dynamics during 1997 and 1998: Anomalous conditions in the Bering Sea. MS thesis, University of Alaska-Fairbanks, Fairbanks

Robson BW, Goebel ME, Baker JD, Ream RR, Loughlin TR, Francis RC, Antonelis, GA, Costa DP (2004) Separation of foraging habitat among breeding sites of a colonial marine predator, the northern fur seal (Callorhinus ursinus). Can J Zool 82:20-29

Roppel AY, Davey SP (1965) Evolution of fur seal management on the Pribilof Islands. J Wildl Manag 29:448-463

Saino T, Hattori A (1987) Geographical variation of the water column distribution of suspended particulate organic nitrogen and its ${ }^{15} \mathrm{~N}$ natural abundance in the Pacific and its marginal seas. Deep-Sea Res I 34:807-827

Scheffer VB (1950) Experiments in the marking of seals and sea lions. US Fish Wildl Serv Spec Sci Rep Wildl 4, Washington, DC

Scheffer VB, Fiscus CH, Todd EI (1984) History of scientific study and management off the Alaska fur seal, Callorhinus ursinus, 1789-1964. NOAA Tech Rep NMFS/SSRF-780, Seattle, WA

Editorial responsibility: Howard Browman (Associate Editorin-Chief), Storebø, Norway
Schell DM (2000) Declining carrying capacity in the Bering Sea: isotopic evidence from whale baleen. Limnol Oceanogr 45:459-462

Schell DM (2001) Carbon isotope ratio variations in Bering Sea biota: the role of anthropogenic carbon dioxide. Limnol Oceanogr 46:999-1000

Schell DM, Saupe SM, Haubenstock N (1989) Bowhead whale (Balaena mysticetus) growth and feeding as estimated by $\delta^{13} \mathrm{C}$ techniques. Mar Biol 103:433-443

Schell DM, Barnett BA, Vinette KA (1998) Carbon and nitrogen isotope ratios in zooplankton of the Bering, Chukchi and Beaufort seas. Mar Ecol Prog Ser 162: 11-23

Sinclair EH, Robson BW (1999) Fur Seal Investigations, 1997. NOAA Tech Memo NMFS/AFSC-106, Seattle, WA

Sinclair EH, Zeppelin TK (2002) Seasonal and spatial differences in diet in the western stock of Steller sea lions (Eumetopias jubatus). J Mammal 83:973-990

Sinclair EH, Loughlin TR, Pearcy W (1994) Prey selection by northern fur seals (Callorhinus ursinus) in the eastern Bering Sea. Fish Bull 92:144-156

Sterling JT, Ream RR (2004) At-sea behavior of juvenile male northern fur seals (Callorhinus ursinus). Can J Zool 82: 1621-1637

Sugimoto T, Tadokoro K (1998) Interannual-interdecadal variations in zooplankton biomass, chlorophyll concentration and physical environment in the subarctic Pacific and Bering Sea. Fish Oceanogr 62:74-93

Towell RG, Ream RR, York AE (2006) Decline in northern fur seal (Callorhinus ursinus) pup production on the Pribilof Islands. Mar Mamm Sci 22:486-491

Trillmich F, Dellinger T (1991) The effects of El Niño on Galápagos pinnipeds. In: Trillmich F, Ono KA (eds) Pinnipeds and El Niño: responses to environmental stress. SpringerVerlag, Berlin

Trites AW (1992) Reproductive synchrony and the estimation of mean date of birth from daily counts of northern fur seal pups. Mar Mamm Sci 8:44-56

Walker JL, Macko SA (1999) Dietary studies of marine mammals using stable carbon and nitrogen isotopic ratios of teeth. Mar Mamm Sci 15:314-334

Warner MJ, Roden GI (1995) Chlorofluorocarbon evidence for recent ventilation of the deep Bering Sea. Nature 373: 409-412

Whitledge TE (1999) Nutrient cycling and phytoplankton growth. In: Macklin SA (ed) Report on the FOCI International Workshop on Recent Conditions in the Bering Sea. Pacific Marine Environmental Laboratory, Seattle, WA, p 13-14

York AE (1990) Trends in numbers of pups born on St. Paul and St. George Islands, 1973-1988. NOAA Techn Memo NMFS F/NWC-180, Seattle, WA

York AE, Hartley JR (1981) Pup production following harvest of female northern fur seals. Can J Fish Aquat Sci 38: $84-90$

Submitted: May 22, 2006; Accepted: September 14, 2006 Proofs received from author(s): January 31, 2007 